\title{
Integrated Entrepreneurship Education through Characteristics of Natural School
}

\author{
$1^{\text {st }}$ Silvia P. Daniati \\ Department of Primary Education, \\ Faculty of Teacher Training and \\ Education Universitas Sebelas \\ Maret Surakarta, Indonesia, Jl. Ir. \\ Sutami 36A Kentingan Jebres \\ Surakarta 57126 \\ silviapuspitaD@gmail.com
}

$2^{\text {nd }} \mathrm{S}$ Subiyantoro

Department of Fine Arts Education, Faculty of Teacher

Training and Education,

Universitas Sebelas Maret,

Surakarta, Indonesia, Jl. Ir.

Sutami 36A Kentingan Jebres

Surakarta 57126

s.biyantoro@yahoo.co.id $3^{\text {rd }}$ Siti S. Fadhilah

Department of Guidance and Counseling Education, Faculty of Teacher Training and Education, Universitas Sebelas Maret. Surakarta, Indonesia, Jl. Ir. Sutami 36A Kentingan Jebres Surakarta 57126

sitisfadhilah@staff.uns.ac.id

\begin{abstract}
The objective of this research was to explore the forms of entrepreneurship education towards the student which was created by natural school. The location of this research was Muhammadiyah Alam Surya Mentari Elementary School Surakarta, Indonesia. This research was qualitative research in the form of case study with in depth study regarding the happening phenomenon and activity. The data collection was by interview, observation, and documentation. The data analysis used the flow model of analysis and sampling was determined according to the objective of the study and so, purposive sampling technique was used. The result of this research showed that natural school reflected the entrepreneurship education through integrated action learning in the sustainable learning process and specific school routine: market day and cooking classroom activities which shapes the mentality for entrepreneurship. The activity was developed based on the needs of the society. Entrepreneurship education gives a career opportunity in the future through a creative and innovative process in natural school.
\end{abstract}

Keywords: entrepreneurship education, integrated, elementary school, natural school

\section{INTRODUCTION}

The fluctuation in population of a country is a sign of an inevitable growth of population which is happened in every country in this world. The ever increasing population presents a challenge for a nation to give prosperity to its people (Christianingrum \& Rosalina, 2017). Prosperity, as a goal, is not been fully received by the people. The fact was there still a high rate of unemployment throughout the world. Based on the statistical report from International Labor Organization (ILO) (2016), there were more than 201 million unemployed workers in 2017, which has increased by 3.4 million from 2016. Moreover, ILO also mentioned the average youth unemployment rate in East Asia is $11.7 \%$ and in Southeast Asia, as much as $13.1 \%$.
Moreover, youth unemployment in Indonesia was at $17.8 \%$, which was higher than China's rate at $12.1 \%$. Another result from ASEAN Secretary Survey (2016) stated that, in 2015, Indonesia has the third highest unemployment rate at $6.2 \%$, below Philippine and Brunei at $6.5 \%$ and $6.9 \%$ respectively.

Indonesian Central Statistic Body (BPI) in 2017 reported that the unemployment rate in Indonesia as of February 2017 was at $5.33 \%$ or 7.01 million people, which then had increased to $5.50 \%$ or 7.3 million people in August 2017. The high number of unemployment, according to Yuwono \& Sumartono (2013) is caused by the discrepancy between education and business world. The orientation of education has not yet emphasize on value of independency and creativity which is a basis for entrepreneurship. Moreover, the education system in Indonesia emphasizes more on the students' achievement and graduation score, and not emphasizing on creating with creative-minded graduates to build a work independency and skill. Therefore, the spirit of entrepreneurship is required for reduce the unemployment rate. The President of Indonesia is also aware of the importance of entrepreneurship by issuing the Presidential Regulation of Republic of Indonesia Number 66 of 2017, regarding cross-sector strategic coordination for youth service that contains inter-sector synergic programs about awareness and empowerment, as well as leadership, entrepreneurship, and youth pioneering for development of the country and improving competitiveness of youth entrepreneurs. Therefore, entrepreneurship needs to be implemented early through the education. Because, based on the data, the majority of workers which graduated only from elementary school education or lower was at $42.13 \%$ or 50.98 million people and the performance report of the President of the Republic of Indonesia in 2017 also noted that the number of elementary school graduates was $4,400,553$ people, while those with 
secondary school graduates were 3,281,121 people. From these data it can be seen that the highest number of graduates were from primary schools and the graduates highly contributes to the number of unemployment in Indonesia.

The high number of primary school graduates compared to the number of unemployed worker indicates a low level of spirit of entrepreneurship in education. According to Deveci \& Cepni (2017), entrepreneurship is one of the important skills and needs to be implemented in basic education. Affandi (2013) also argues that the primary education is the beginning of formal education in Indonesia in order to conduct the integrated entrepreneurial education reforms. Because, with the spirit of entrepreneurship, according to Kirbaslar \& Gunes (2015) and Gaddefors \& Anderson (2017), someone is able to become an entrepreneur, so that they can open up employment opportunities for the unemployed by devoting their knowledge for innovation and creativity, taking risks, and having a strong will to connect and create changes. Entrepreneurship emerges from the context itself, being an individual and social object which interacts with each other. By implementing the spirit of entrepreneurship at the elementary school, it is expected that elementary school graduates will have a good entrepreneurial spirit to be used in their daily lives.

Implementing spirit of entrepreneurship in primary school is not a simple matter. The form of education which integrated with spirit of entrepreneurship on primary school level must first be understood. Nielsen \& Gartner (2017) stated that the school program which implements the spirit of entrepreneurship is required to have commitment, able to make serious effort, and strive to prepare and support the student in building their spirit of entrepreneurship. Moreover, Asici \& Aslan (2010) stated about the importance of the teacher's and students' view towards spirit of entrepreneurship through acquiring confidence, high curiosity, enjoying the process of searching, and able to create. The results of Moberg's (2014) study also added that entrepreneurship education that focuses on content and cognitive skills has a positive influence on entrepreneurial interest but has a negative impact on the level of school involvement. For entrepreneurship, the education system must be in line with the purpose of education, by creating education for students to continue to advance and develop by acquiring entrepreneurship skills. The cognitive, affective, and psychomotor aspects must be balanced with the learning process or be structured on the topic of the school.

Therefore, the spirit of entrepreneurship are able to be developed in primary school education by balancing the cognitive, affective, psychomotor, and then through school programs that are able to make something new through action learning with strong commitment. Furthermore, the learning process must also be more structured in instilling the spirit of entrepreneurship, which are; self-confidence, initiative, creative, risk-taker, never give up, leadership, and responsible. The development has actually been applied in elementary school culture in the natural school, which is currently growing rapidly in Indonesia. Natural schools are schools that give different atmosphere and a place for new change with stronger commitment compared to formal schools in general which lacks the exploration of the spirit of entrepreneurship. According to Rohinah (2014), natural schools provide opportunities for students to experiment, explore their knowledge without being restricted by walls, by stimulating their curiosity, and developing their characteristic, with noble quality, and knowledgeable. Spalie (2011) also argues that natural schools can provide strong characters because students are not required to accomplish achievement and they are able to learn to live their lives outside school with the concept of learning which is integrated with the surrounding environment. In addition, Shodiq, et al (2006: 9), states that children in primary school age have a different world without being isolated from the outside world. Natural School views the students as a subject who is invited to develop their potential from an early age with a school culture that does not burden them. If the students are not burdened, then they can develop themselves through a natural school culture that is integrated with the spirit of entrepreneurship. Natural schools are able to answer the challenges of education based on entrepreneurship.

Based on the description above, the goal of this research was to explore the form of education that implements the spirit of entrepreneurship to the students which was created by natural school culture on primary school level and integrated through the natural school's program and the learning activity that emphasize on action learning.

\section{METHOD}

This research was a qualitative research with in-depth descriptions of the situation or occurrence of the implementation of natural schools in instilling entrepreneurial spirit. In accordance with Moleong's opinion (2012: 6), qualitative research is a description with scientific method in the form of words and language in natural context such as behavior, perception, motivation to the phenomenon which happened. This qualitative research strategy used case studies; according to Emzir (2014: 20) case study research is a study that finds the meaning of the phenomenon that occurs by conducting an inquiry to obtain profound results on the situation. This research was conducted in Muhammmadiyah Alam Surya Mentari Elementary School, which is located on J1. Siwalan No. 45 Kerten, Surakarta, Jawa Tengan, Indonesia. The subjects of this research were third grade students and teachers.

The main instrument in qualitative research is the researcher himself (Nasution, 1996: 9). Although humans were the main instrument, this research also used data collection techniques, which was through interviews, observation, and documentation. 
According to Creswell (2012: 267) observations are made by going directly to the field to observe the behavior and individual activities. The observations in this research were non-participant observations. Interviews were conducted with structured interviews using questionnaire instruments, as well as unstructured interviews with a flexible and opennature to extract information about the situation. Then, the documentation used technique from Yin (2013: 104) which states that document is a supporter and evidence for other sources on research. The document used in this research was the experience of teachers and students in viewing the spirit of entrepreneurship, photo documentation, voice recording for evidence of the event when observed, as well as the implementation plan of learning and school programs.

This research used purposive sampling technique. Purposive sampling is a technique of determining samples with certain considerations that have the requirements and objectives of the study (Sugiyono, 2013: 124). This technique was chosen based on the aim of the researcher in using natural school, Muhammadiyah Alam Surya Mentari Elementary School, based on various supporting aspects that have been adapted to the research objectives. The technique of data validation was by using triangulation of source and method. Triangulation according to Moleong (2012: 178) is utilizing something else outside the data for the purposes of checking or as a comparison to the data. This research was also done by applying flow model of analysis from Mills and Huberman, because this research used single holistic case study. The stages were data reduction, data display, and verification.

\section{RESULTS AND DISCUSSION}

Muhammadiyah Alam Surya Mentari Elementary School is a school that does not emphasize academic achievement but rather emphasizing on providing direct experience with children through actively conducting programs designed by schools, with the provision of freedom in the development of the expected potential that can be useful for their life in the future by adapting to surrounding environment. There are several school programs which designed to develop the students' spirit of entrepreneurship; market day and cooking classroom activities, which are described below:

\section{A. Market day}

This activity is conducted once a year, usually held in March. Each class drafts a concept to be displayed in the event. Cooperation is done by teachers, students, and parents. Sahin (2010) stated that positive school culture will make administrators more creative and efficient in implementing school programs. A school culture that is independent and brave will be felt positively by teachers in developing their activities.
The interview with the headmaster states that market day was held on one day with different themes. The students know and try to decorate the class according to the theme that the class assigned. In every market, the students sell by transacting. The market trades the work of students in the class, such as figure or pot that depends on the teacher class. Teachers will show their creativity to showcase the best of the schooldefined theme. Nature was also a source of learning and nature becomes an infinite laboratory. Thus, the market day activity will also develop the potential of teachers.

The purpose of market day was to educate the students on entrepreneurship in order to create their own field of profession. The students not only become aware of the profession of doctors, police, or soldiers who are paid monthly wage, but children were trained early in the process of earning profit. Students are also able to manage the merchandise that has been prepared in each class with different themes. Products were sold in the form of handmade goods by the students, with the students creating the goods with their own creativity and their collaboration with the parents. Chou, et al (2014) argues that character development is maximized by the integration of relationships between parents and children. His research explains that not only the school, but the parents were also influential. In accordance with that opinion, Prabhu \& Thomas (2014) states that the parents has a positive role on the spirit of entrepreneurship of the students in terms of modeling, family culture, and the qualifications of parents. Thus, market day activities that collaborate with parents will be able to influence the spirit of entrepreneurship of the students. Furthermore, the concept of market should also provide information which were integrated with the knowledge in accordance with the theme.

On March $16^{\text {th }}, 2018$, a market day was held with the theme of "Surya Mentari Penembus Pasar Dunia" (Surya Mentari Breaking Through Global Market). Each class has its own themes from around the world; there are countries of Indonesia, Malaysia, China, Arab, Italy, Singapore, America and five other countries. Class III A as the observed class receives the theme of United States of America. The teachers collaborate with students to create American trinkets such as flags, 10 names of U.S. presidents, and American writing. In addition, the teachers also collaborate with parents in making American specialties (Sandwich, Hot Dogs, and French fries) and also in making the landmark of U.S.A. which is the statue of Liberty as the symbol of the country. In addition to selling in their own stall, the students also offer their goods to other stalls around to train the way of socializing and creativity in offering their goods. Students also travel to other stalls to obtain information about other countries and purchase products offered at each stalls. 

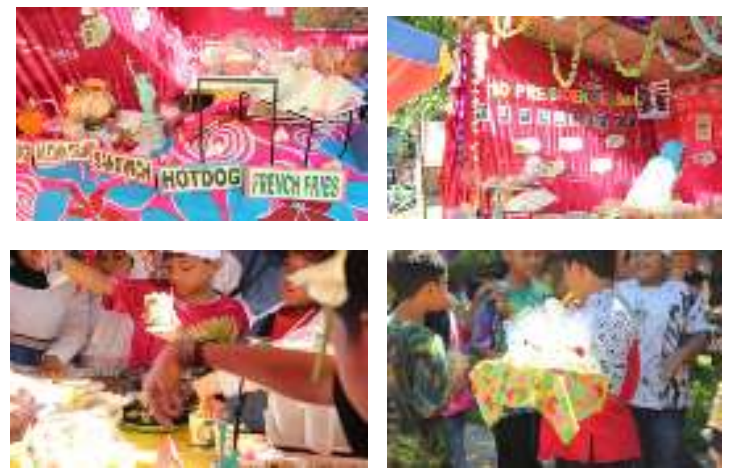

Figure 1. Market Day activity of the Third Grade with the theme of "United States of America"

The character development in elementary school, according to Sardjijo \& Ali (2017), should be centered on students with the students themselves trying to directly gain experience. Integration is done in a meaningful, flexible, and holistic way, and through active students' participation. It can be seen that market day activity provides direct experience to the students, where the students can practice bargaining procedures, how to dress according to the given theme, getting information such as the characteristics of countries in the world, and have creativity in making the product and decorating the stall. This school also has a large area with natural surroundings; the activity is done inside the school outside the classroom without jostling in the process of market day.

\section{B. Cooking Classroom Activities}

The cooking classroom activities program was created based on the concept of an independent natural school and action learning activities. Jagannathan (2018) stated that natural schools are able to stimulate students in preparing for their future lives according to their potential. The enthusiasm between teachers and students is tailored to the school culture, and the process of learning in the concept of learning should be integrated with the natural environment. Based on the results of interviews, children were introduced as early as possible in solving problems so that children know the process better, they observe and gain knowledge through cooking classroom activities. The activity was held twice in a year at each semester break. The class was not about freely processing food, but every class was given a theme. The themes that have been done were Indonesian cuisine, processed fish, processed tubers, etc.

In the cooking classroom activities at Muhammadiyah Alam Surya Mentari elementary school, children buy food ingredients together and also learn how to bid, buy, and transact. In addition, children were also introduced with the processing of food materials which they use. For example, if using chicken as a food ingredient, they must learn how to slaughter the chicken until the process of serving the dish. All students have their own role, the teachers divide students into groups; there were groups that shop, fry, and chop, as well as group that present the food. In addition, based on interviews and observations, unlike the market day that has the concept of selling the results, cooking classroom activities emphasize more on sharing with others to enjoy the results of cooking. Each class give their cooking to other class and teachers so they were able to enjoy and taste all cooking result of each class. Andayani, et al (2017) argues that the application of real-world learning and the development of the economic potential that exists around schools are essential for the development potential of natural resource management. Thus, through cooking classroom activities, students are able to process natural resources in their application in the school environment and able to develop them on their spirit of entrepreneurship.

\section{Learning Integration}

Natural school not only designs spirit of entrepreneurship through school programs, but also through learning activities. The learning material also has the concept of interconnected web spiders and collaborated with spirit of entrepreneurship. Therefore, Musoke \& Badru (2018) stated that entrepreneurial activity can be maximized through learning innovation. Learning innovation can develop the students' social values and initiatives to support education. Paiva \& Tadeu (2015) also stated that entrepreneurship is about the ability to put up ideas and act through a problem-based learning process by developing creative ideas. Creative integration in learning in the educational curriculum can achieve innovation and ideas in a real-life context. It should be noted that not all materials can be integrated with the spirit of entrepreneurship. Therefore, there was only a certain material or theme which could be integrated.

Some Third Grade thematic materials that integrated with the entrepreneurial spirit created by the teacher through the implementation plan of learning based on the learning syllabus were; (1) Learning in the fruit market with the practice of buying and selling directly, then during the trip to the fruit market students observe the types of professions. The purchased fruit was then cut to introduce simple shards, and finally the students tell their experiences of the day (Bahasa Indonesia, Mathematics, and Social Sciences); (2) Understanding Javanese script and the big day of Islam, the students then cut Javanese script and the color it and stick it in sequence with their own creativity (Islam, Javanese, and Arts); (3) Listing the tools that use electrical energy in the area around the school, then make windmills from 
used water bottles, and also write and tell the procedures of making windmill (Science, Arts, Bahasa Indonesia); (4) Natural school also provides environmental education material that is conducted once every week, its activities consists of practicing how to plant vegetable seedlings, practicing soil management, and telling the process of processing and planting vegetable seedlings. Kamaruddin (2012) states that the character of each student cannot be developed through one or two activities, but must be continuous and integrated through the learning process. In addition, Hashim \& Denan's (2015) study results suggest that if students are less likely to interact with nature, students will tend to think the outside of classroom will not help in students' creativity. Thus, the concept of web spiders and interaction with nature can give meaning to students.

Also note one of the characteristics of the Muhammadiyah Alam Surya Mentari Elementary School was not to giving the burden of books on the students. The teachers in carrying out every lesson always make the worksheet as a challenge for students to complete it every day. Worksheet was used as a substitute for books and demands the creativity of teachers in the provision of worksheets in implementing concept of learning. Worksheet was one form of student freedom in the school of nature. In accordance with Nursanti, et al (2016) which states that in school culture that puts pressure on students to master knowledge and accepts only information provided by teachers without providing critical thinking opportunities and explores innovative ideas, it will be difficult to achieve the goal of expected character development. Thus, the worksheet with the various problems it offered can provide an opportunity for students to develop creative ideas and innovation.

Observation indicator which was used in this research was the seven spirits of entrepreneurship, which were (1) confidence; (2) initiative; (3) creativity; (4) risk taking; (5) never giving up; (6) leadership; (7) responsibility. The seven indicators of spirit of entrepreneurship are the indicators for observing students in school programs and learning process. The scoring criteria are $1=$ never; $2=$ sometimes; 3 = often; 4 = always. Observations result can be seen in the indication table below:

TABLE 1. SPIRIT OF ENTREPRENEURSHIP INDICATOR

\begin{tabular}{llcccc}
\hline \multirow{2}{*}{ No } & Indicator & \multicolumn{4}{c}{ Score/Number of student } \\
\cline { 2 - 5 } & $\mathbf{1}$ & $\mathbf{2}$ & $\mathbf{3}$ & $\mathbf{4}$ \\
\hline 1 & $\begin{array}{l}\text { Confidence } \\
\text { a } \quad \begin{array}{l}\text { Learning with } \\
\text { confidence }\end{array}\end{array}$ & - & 4 & 11 & 6 \\
& b $\quad \begin{array}{l}\text { Acting without } \\
\text { dependence }\end{array}$ & - & 5 & 8 & 8 \\
& Percentage & - & 21,43 & 45,24 & 33,33 \\
2 & Initiative & & $\%$ & $\%$ & $\%$
\end{tabular}

\begin{tabular}{|c|c|c|c|c|c|}
\hline \multirow{2}{*}{ No } & \multirow{2}{*}{ Indicator } & \multicolumn{4}{|c|}{ Score/Number of student } \\
\hline & & 1 & 2 & 3 & 4 \\
\hline & $\begin{array}{ll}\text { a } & \text { Trying } \\
& \text { something as } \\
& \text { wished }\end{array}$ & - & 2 & 11 & 8 \\
\hline & $\begin{array}{ll}\text { b } & \text { Giving } \\
\text { suggestion }\end{array}$ & - & 6 & 9 & 6 \\
\hline & Percentage & - & $\begin{array}{c}19,05 \\
\%\end{array}$ & $\begin{array}{c}47,62 \\
\%\end{array}$ & $\begin{array}{c}33,33 \\
\%\end{array}$ \\
\hline 3 & $\begin{array}{l}\text { Creativity } \\
\text { a Thinking to } \\
\text { create something } \\
\text { new }\end{array}$ & - & 6 & 9 & 6 \\
\hline & Percentage & - & $\begin{array}{c}28,57 \\
\%\end{array}$ & $\begin{array}{c}47,62 \\
\%\end{array}$ & $\begin{array}{c}33,33 \\
\%\end{array}$ \\
\hline 4 & $\begin{array}{l}\text { Risk Taking } \\
\text { a Brave and } \\
\text { willing to take } \\
\text { risk in doing } \\
\text { task }\end{array}$ & - & 3 & 11 & 7 \\
\hline & b Like challenges & - & 3 & 12 & 6 \\
\hline & Percentage & - & $\begin{array}{c}14,29 \\
\%\end{array}$ & $\begin{array}{c}54,76 \\
\%\end{array}$ & $\begin{array}{c}30,95 \\
\%\end{array}$ \\
\hline 5 & $\begin{array}{l}\text { Never Giving Up } \\
\text { a Try and rise up } \\
\text { when failing }\end{array}$ & - & 5 & 10 & 6 \\
\hline & Percentage & - & $\begin{array}{c}23,81 \\
\%\end{array}$ & $\begin{array}{c}47,62 \\
\%\end{array}$ & $\begin{array}{c}28,57 \\
\%\end{array}$ \\
\hline 6 & $\begin{array}{l}\text { Leadership } \\
\text { a Open to } \\
\quad \text { suggestion }\end{array}$ & - & 4 & 10 & 7 \\
\hline & $\begin{array}{l}\text { b Easy to socialize } \\
\text { and work with } \\
\text { others }\end{array}$ & - & - & 7 & 14 \\
\hline & Percentage & - & $9,52 \%$ & $\begin{array}{c}40,48 \\
\%\end{array}$ & $50 \%$ \\
\hline 7 & $\begin{array}{l}\text { Responsibility } \\
\text { a Doing task } \\
\\
\text { wholeheartedly }\end{array}$ & - & 6 & 9 & 6 \\
\hline & $\begin{array}{ll}\text { b } & \text { Every given } \\
\text { tasks are always } \\
\text { done }\end{array}$ & - & 3 & 10 & 8 \\
\hline & Percentage & - & $\begin{array}{c}21,43 \\
\%\end{array}$ & $\begin{array}{c}45,24 \\
\%\end{array}$ & $\begin{array}{c}33,33 \\
\%\end{array}$ \\
\hline Total & & - & 47 & 117 & 88 \\
\hline Perce & $\overline{\text { ntage }}$ & - & $\begin{array}{c}18,65 \\
\%\end{array}$ & $\begin{array}{c}46,43 \\
\%\end{array}$ & $\begin{array}{c}34,92 \\
\%\end{array}$ \\
\hline
\end{tabular}

According to the tabel 1 can be known that the integration of spirit of entrepreneurship in natural school, exist $18,65 \%$ students who sometimes have spirit of entrepreneurship, 46,43\% students often have spirit of entrepreneurship, and $34,92 \%$ students always have spirit of entrepreneurship.

TABLE 2. STUDENT BEHAVIOR

\begin{tabular}{cccc}
\hline $\begin{array}{c}\text { Score } \\
\text { Interval }\end{array}$ & $\begin{array}{c}\text { Number of } \\
\text { student }\end{array}$ & Percentage & Category \\
\hline $1-12$ & - & - & Not Seen \\
$13-24$ & - & - & Start Visible \\
$25-36$ & 13 & $61,90 \%$ & Start Culture \\
$37-48$ & 8 & $38,10 \%$ & Already \\
& \multicolumn{4}{c}{ Culture } \\
\hline Total & 21 & $100 \%$ & \\
\hline \multicolumn{4}{l}{ According to the tabel 2 can be known that }
\end{tabular}
students start to be entrenched their spirit of entrepreneurship as many as 13 students or $61,90 \%$ and had been entrenched 8 students or $38,10 \%$ with the whole number as many as 21 students of class III A. 


\section{CONCLUSION}

Based on research conducted at Muhammadiyah Alam Surya Mentari Elementary School, Surakarta, Indonesia, it can be concluded that the integration of spirit of entrepreneurship was done through several school programs such as market day and cooking classroom activities and also through the integration of learning with the concept of spider web. In each activity, students gain experience directly by trying their own to solve every given challenge.

In some activities which have been carried out, parents and educational personnel also participated in the implementation of the activities. This shows the strong cooperation between teachers, students, parents, and education personnel. The spirit of entrepreneurship shown in this study were; $18,65 \%$ were categorized as sometimes, $46,43 \%$ were categorized as frequent, and $34,92 \%$ were categorized as always. Thus, the processes undertaken in natural schools can develop the students' spirit of entrepreneurship.

Natural school must also always provide innovative activities in either school programs or learning process, so that natural schools which are still considered as an alternative school can be trusted by the public as a whole. Therefore, the researchers recommended that natural schools, with different characteristics than primary schools in general, to be able to give a good impression in the development of spirit of entrepreneurship. Early entrepreneurship education is able to develop strong characters which can be used in the future life to response all life challenge.

\section{ACKNOWLEDGMENTS}

The authors would like to give a sincere gratitude to the two mentoring lecturers, Subiyantoro, and Fadhilah for their guidance and direction to carry out this research and article writing.

\section{REFERENCES}

[1] Afandi, R. (2013). Penanaman Jiwa Kewirausahaan pada Siswa Sekolah Dasar. Jurnal Pemikiran dan Pengembangan SD, 1(2), 10-19.

[2] Andayani, E., Srihariani, L., Winarsih, S., \& Rusno. (2017). Contribution of School's Characters to the Effectiveness of Entrepreneurial Learning Based on Local Wisdom. International Journal of Pedagogy and Teacher Eduation (IJPTE), 1(1), 37-45.

[3] Asici, H., \& Aslan, S. (2010). The views of primary school 6th,7th and 8th year students and teachers regarding entrepreneurship. Procedia Social and Behavioral Science, 9, 1731-1735.

[4] Badan Pusat Statistika. (2017). Keadaan Ketenagakerjaan Indonesia Agustus 2017. 20 Mei 2018 retrived from https://www.bps.go.id

[5] Chou, Ju, M., Yang, Hsin, C., Huang, \& Chen, P. (2014). The Beauty of character Education on Preschool Children's Parent-Child Relationship.
Procedia Social and Behavioral Sciences, 143, 527-533.

[6] Christianingrum., \& Rosalina, E. (2017). Pengaruh Pembelajaran Kewirausahaan terhadap Minat Berwirausaha. Integrated Journal of Business and Economics (IJRE), 1 (1), 45-55.

[7] Creswell, J. W. (2012). Research Design Pendekatan Kualitatif, Kuantitatif, dan Mixed. Yogyakarta: Pustaka Pelajar.

[8] Deveci, I., \& Cepni, S. (2017). Studies Conducted on Entrepreneurship in Science Education : Thematic Review of Research. Turkish Science Education (TUSED), 14(4), 126143.

[9] Emzir. (2014). Metodologi Penelitian Kualitatif. Jakarta: PT Raja Grafindo Jakarta.

[10] Gaddefors, J., \& Anderson, A. R. (2017). Entrepreneursheep and context: when entrepreneurship is greater than entrepreneur. International Journal of Entrepreneurial Behavior \& Research, 23(2), 267-278.

[11] Hashim, H. H., \& Denan, Z. (2015). Impoetance of Preserving the Natural Environment in the Design School in Malaysia. Procedia- Social and Behavioral Science, 170, 177-186.

[12] International Labour Organization (ILO). (2016). Tinjauan Pasar Kerja Indonesia. 20 Mei 2018 retrived from www.ilo.org.pdf

[13] Jagannathan, R., Camasso, M. J., \& Delacalla, M. (2018). The effectiveness of a head-hearthands modal for natural and environmental science learning in urban schools. Evaluation and Program Planning, 66, 53-62.

[14] Kamaruddin, S. A. (2012). Character Education and Students Social Behavior. Journal of Education and Learning, 6(4), 223-230.

[15] Kirbaslar, M., \& Gunes, Z. O. (2015). The effect of critical thinking disposition on entrepreneurship levels: A study on future teacher. Procedia Social and Behavioral Sciences, 174, 199-207.

[16] Laporam 3 Tahun Pemerintahan Joko Widodo-Jusuf Kalla. (2017). Sidang Kabiner Paripurna. 20 Mei 2018 retrived from presidenri.go.id/wp-content/.../FINAL_LAPORAN-3TAHUN.pdf

[17] Moberg, k. (2014). Two approaches to entrepreneurship education: the different effects of education for and through entrepreneurship at the lower secondary level. The International Journal of Management Education, 12, 512-528.

[18] Moleong, L. J. (2012). Metodologi Penelitian Kualitatif. Yogyakarta: PT Remaja Rosdakarya.

[19] Musoke, G. G., \& Badru, M. (2018). Educational Entrepreneurship (EE): Delineating and Highlighting Its Domain, Importance and Feasibility in Uganda's Context. Journal of Education and Learning (EduLearn), 12(1), 126136.

[20] Nasution, S. (1996). Metode Penelitian Naturalistik Kualitatif. Bandung: Tarsito.

[21] Nielsen, S. L., \& Gartner, W. B. (2017). Am I a student and/or entrepreneur? Multiple identities in student entrepreneurship. Education + Training, 59(2), 135-154.

[22] Nursanti, Y. B., Rochsantiningsih, D., Joyoatmojo, S., \& Budiyono. (2016). Mathematics Education Model in Indonesia Through Inquiry-Based Realistic Mathematics Education Approach to Improve Character. International Journal of Education and Research (IJERN), 4(9), 323-332.

[23] Paiva, T., \& Tadeu, P. (2015). An approach project to develop entrepreneurship in primary 
schools. Procedia Social and Behavioral Sciences, 174, 1908-1915.

[24] Peraturan Presiden Republik Indonesia. (2017). Koordinasi Strategis Lintas Sektor Penyelenggaraan Pelayanan Kepemudaan Peraturan Presiden Nomor 66 Tahun 2017. 20 Mei 2018 retrived from kemenpora.go.id.pdf

[25] Prabhu, A., \& Thomas, A. (2014). Influence of Parental Factors on the Entrepreneurial Attitude of B School Students. International Journal of Research and Development A Management Review (IJRDMR), 3(1), 35-38.

[26] Rohinah. 2014. Sekolah Alam: Paradigma Baru Pendidikan Islam Humanis. Jurnal Pendidikan Islam, 8(2), 281-294.

[27] Sahin, S. (2010). An Investigation of School Culture with Respect to Some Variables. Elementari Education Online (EEO), 9(2), 561-575.

[28] Sardjijo, \& Ali, H. (2017). Integrating Character Building nto Mathematics and Science Course in Elementary School. International Journal of Environmental \& Science Education, 12(6), 1547-1552.
[29] Shodiq, S., Amien, M. S., \& Babussalam, B. (2006). Sukses Melejitnya Potensi Anak Didik. Bandung: MLC.

[30] Spalie, N., Utaberta, Abdullah, Tahir, M., \& Ani, C. (2011). Reconstructing Sustainable Outdoor Learning Environment in Malaysia from the Understanding of Natural School Design and Approaches in Indonesia. Procedia-Social and Behavioral Science, 15, 3310-3315.

[31] Sugiyanto. (2013). Metode Penelitian Pendidikan Pendekatan Kuantitatif, Kualitatif, dan $R \& D$. Bandung: Alfabeta.

[32] Survey ASEAN Secretary. (2016). Tingkat Pengangguran di Negara Anggota ASEAN. $20 \mathrm{Mei} 2018$ retrived from https://databoks.katadata.co.id

[33] Yin, R. K. (2013). Studi Kasus Desain dan Metode. Jakarta: PT Raja Grafindo Persada.

[34] Yuwono, Endro, \& Sumartono, G. H. (2013). Strategi Menumbuhkan Wirausahawan Muda dari Kampus. Prosiding Konferensi Nasional "Inovasi dan Tecknopreneurship" (hal. 40-46). Bogor:

RAMP

IPB. 